\title{
Effect of Information and Knowledge Sharing on Supply Chain Performance: A Survey Based Approach
}

\author{
Choudhury Abul Anam Rashed \\ Shahjalal University of Science and Technology \\ rashed_sust@yahoo.com
}

\author{
Abdullahil Azeem \\ Bangladesh University of Engineering and Technology \\ azeem@ipe.buet.ac.bd
}

\section{Zaheed Halim \\ Deakin Univerisity \\ ibne@lycos.com}

\begin{abstract}
Supply chain management emphasizes the overall and long-term benefit of all parties on the chain through cooperation and information sharing. Recently, information sharing is attaining the concentration of the researchers. Majority of the previous work is on the individual effect of information and knowledge sharing on performance. This paper aims to focus on the combined consequence of information and knowledge sharing on supplier's operational performance through supplier-buyer relationship. A conceptual model was formulated based on previous literature. A questionnaire based survey was performed. Data from 30 Bangladeshi Readymade Garments Industry were collected through interview and mail survey. The content validity, construct validity, and reliability are tested. Path Analysis is performed for the identification of the validity of the model. The findings show that information sharing is a prerequisite for knowledge sharing and the close supplier-buyer relationship is a vital factor for escalating the supplier's operational performance.
\end{abstract}

Keywords- Information Sharing, Knowledge Sharing, Supplier-Buyer Relationship, Suppliers' Operational Performance.

\section{INTRODUCTION}

Supply chain involves the flow of both tangible and intangible resources including materials, information and capital across the entire supply chain. Supply chain practice focuses on material movement while information sharing focuses on information flow. Two major aspects of information sharing are information content and information quality. Information content refers to the information shared between suppliers and buyers. Information quality measures the quality of information shared between suppliers and buyers [1]. There are two dimensions of information sharing- connectivity and willingness. Both dimensions are found to impact operational performance and to be critical to the develop- ment of a real information sharing capability [2]. The value of information-sharing can be defined as the benefits derived from sharing information minus the associated costs.

High performing firms had a higher percentage of information exchanged via EDI with customers and suppliers. Their results demonstrated that information technology investment alone is not enough. Only when management teams emphasize on the technology investment and choose the appropriate information to share, a firm can achieve effective firm performance. The face-to-face communication can raise the level of information sharing. When companies are willing and able to share vital- and often proprietary decision-making information, trust can 
be established and collaboration will be promoted. Technology becomes a tool to augment and promote information sharing and real collaboration.

A knowledge shared supply chain is an evolution over an information shared supply chain. Knowledge in the business context is nothing but a more valuable and actionable information. Knowledge allows for making predictions, casual associations, or predictive decisions about what to do, unlike the information that simply gives us the fact [3]. Knowledge starts its life as data, unrelated facts that have little value of their own. As data is combined and placed in a context, it becomes information. Information becomes knowledge through critical and creative thought processes. Knowledge can be classified as tacit and explicit [4]. Tacit knowledge has two dimensions both personal and practical. It is embedded in people's ideas, values and emotions and is expressed more in people's actions. It is their 'know-how' and shapes the way they perceive the world.

The descriptions of relationships are relatively abstract and vary with the discipline from which they are being researched (e.g. strategy, economics or psychology). As soon as two or more parties (i.e. organizations) associate themselves in order to fulfill a mutual business purpose a relationship is established [5]. Such an association leads to various joint activities, which are dependent on the specific business objective. Buyer-supplier relationships are classified as- adversarial arm's-length approach and partnerships approach [6]. The difference between, traditional arm's-length relationships and partnerships is clear - partnerships are closer than other types of relationship. Relationships are seen as having positive links to performance but little is known about the nature of this performance. Relationships themselves can be seen as generic; applying to all buyer-supplier exchanges. Relationships are viewed as mutual, two-way, involved exchanges between buyers and suppliers. It is apposite, therefore, to bring a relationship performance viewpoint to this key nexus of a firm's operation.

Past studies show that buyers benefit when suppliers are intensively and durably involved in information exchange, it is less clear under what conditions this improves supplier's operational performance. Majority of the research work has emphasized the individual effect of information and knowledge sharing on supply chain (specifically buyer) perfor- mance and the individual effect of information and knowledge sharing on buyer-supplier relationship. In this paper it is tried to show the combined effect of information and knowledge sharing on the buyersupplier relationship and the effect of the relationship on supplier's operational performance. The objectives of the present study are- to investigate the combined effect of operational information and knowledge sharing on supplier-buyer relationship and to explore the impact of the mentioned relationship on supplier's operational performance. Possible outcome of the research is the determination of linkage between information and knowledge sharing with buyer-supplier relationship and evaluation of the effect of this relationship on suppliers' operational performance.

\section{LITERATURE REVIEW}

A number of researchers have identified several important characteristics of information quality Neumann and Segev [7] studied four information characteristics: content, accuracy, recency and frequency. McCormack [8] measured information by accuracy, frequency, credibility, and availability of forecast. Petersen [9] measured information quality by currency, accuracy, and completeness. Vijayasarathy and Robey [10] measured information intensity and quality. Information quality is an important determinant of the usefulness of an information system. Sum et al. [11] found that data accuracy is critical in affecting operating efficiency and customer service. McGowan [12] argued that the information system is perceived useful when the information is high quality, readily accessible, accurate and relevant [1].

Many researchers who have approached proved that increased visibility will improve the performance of the supply chain. But the result from Kaipia R. and Hartiala H. [13] states that if the manufacturer uses its available information about historical demand intelligently, there is no need to invest in informationsharing. To respond productively to rapid change, a company must "be aware of new information generated in its environment and adopt structures that enable fast decision making and practices that reduce information overload [14]. For this reason, companies are investing heavily in information technologies to enhance their ability to manage information and knowledge across the supply chain [15]. Graeml et al. [16] studied about the impact of the Internet and other information technologies on supply chain management, as perceived by managers in the field. 
Many managers mistakenly concentrate their information sharing on only the hardware and software, ignoring the decision-making in the information sharing process. Kaipia R. and Hartiala H. [13] suggested that what makes the performance difference is how information is used.

Knowledge is the key to the success of a supply chain as it affects decisions [3]. Most scholars divide knowledge into two types: (1) explicit knowledge or information, and (2) tacit knowledge or know-how [4]. Information includes facts, axiomatic propositions, and symbols' [17]. By comparison, know-how involves knowledge that is tacit, 'sticky,' complex, and difficult to codify [17]. The properties of knowhow suggest that, compared to information, knowhow is more likely to result in advantages that are sustainable [18]. Explicit knowledge is readily transmitted between people and "defines the intellectual assets of an organization independently of its employees" [19]. Tacit knowledge flows from the people in the organization to be made explicit in its policies, processes and practices [4].

Business relationships have been defined very differently in the literature, ranging from "good business relationships [are] relationships customized to fit the appropriate position on a continuum of possible relationship styles" [20] to "inter-organizational relationships are the relatively enduring transactions, flows, and linkages that occur among or between an organization and one or more organizations in its environment" [21]. Researchers have developed descriptions of many types of relationships. Gummesson [22] defined 30 forms of relationship alone and this illustrates the diversity of viewpoints on the concept of relationships. A key business relationship, in which two parties associate, is that between a buyer and a supplier [6].

Supplier management is no longer focused on just transactions and price negotiations, but concentrates on a wider range of issues. Today, the aim of supplier management is to achieve an optimal flow of high-quality, value-for-money materials and/or components from innovative suppliers [23]. In this situation, the new role of the purchasing manager has been described as an "information exchange broker" [24].

In the current business environment that buyers face, relationships should not be concerned simply with maximizing the difference between purchasing costs and the sales price - there needs to be the development of lasting relationships [25]. Leenders and Fearon [26] highlighted this in saying that "the whole art of supplier relationship management from a supply perspective is to bring both sides into an effective working relationship"

Zhenxin et al. [27] study illustrates the benefits of supply chain partnerships based on information sharing. A close relationship means that channel participants share the risks and rewards and have willingness to maintain the relationship over the long term [28]. Hahn et al. [29], in their conceptual study, provide some useful insights to compare the potential costs associated with different sourcing strategies and the companies will gain benefits by placing a larger volume of business with fewer suppliers using long-term contracts. Furthermore, through a well-developed long-term relationship, a supplier becomes part of a well-managed supply chain and "it will have a lasting effect on the competitiveness of the entire supply chain" [30]. De Toni and Nassimbeni [31] found that a long-term perspective between the buyer and supplier increases the intensity of buyer-supplier coordination. Carr and Pearson [32] investigate the impact of 'strategic purchasing' on 'buyer-supplier relationships' and the subsequent impact of 'buyer- supplier relationships' on the 'firm's financial performance.

Dwyer et al. [33] describes a continuum of different types of buyer-supplier relationships. According to him Japanese auto firms cultivate their suppliers through investments, sharing of knowledge, and joint problem solving. Noordewier et al. [34], state that purchasing performance is an important determinant of a firm's competitiveness. Establishing long-term relationships with the key suppliers can lead to improved firm's financial performance [35]. According to Larson [36], purchasing coordination of the firm's activities with key suppliers can impact total costs. Ford's success demonstrates that businesses can increase their competitiveness by implementing cooperative supplier relationships [37]. Filho et al. [38] analyzed the extent of strategic alignment in the Brazilian automotive chain by examining the strategies adopted by the Purchasing function in the frst tier suppliers for managing relationships with their suppliers. Freires and Guedes [39] described and analyzed the influence of power and the trust among players over performance (effectiveness and efficiency) of Reverse Logistics Systems. All of the literatures were highlighted on the buying firm's performance. No research work was 
performed on the performance from the supplier's perspective. But the positive influence of buyer-supplier relationship emphasizes the probability of having positive link between relationship and suppliers performance.

\section{CONCEPTUAL MODEL AND HYPOTHESES}

Much has been written about SCM in recent years. While the discussion typically revolves around closer collaboration among members of the chain, the perspectives and prescriptions vary greatly. However, one tenet appears as a common thread tying the discussion together: success depends on managers' ability to identify changes in the competitive envi- ronment and then to structure SC resources to help the company compete more effectively. This contingent response determines how well the firm, and the entire chain, adapts to dynamics of an evolving and intensely competitive market.

\subsection{Conceptual Model}

Figure 1 shows the effect of operational information on performance and on supplier-buyer relationship. It also depicts the link between information and knowledge sharing and then the impact of knowledge based information sharing on supplier-buyer relation and the links of supplier-buyer relation to operational performance of supplier. The paths in the model are denoting the hypotheses.

\section{Figure 1: The Conceptual Model}

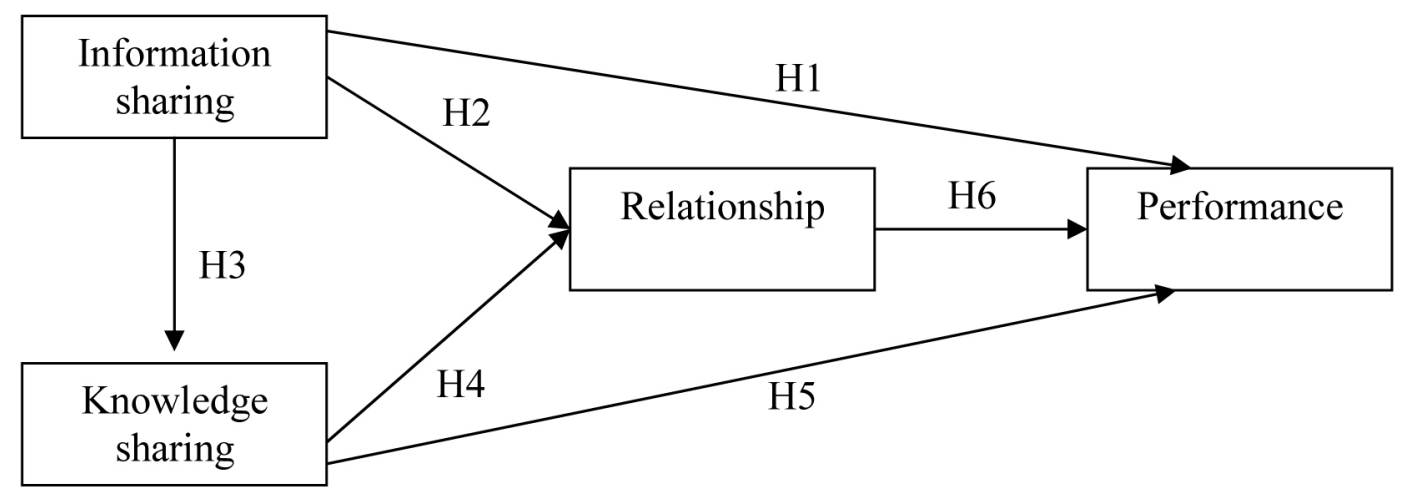

\subsection{Hypothesis}

Hypothesis is a "tentative assumption or preliminary statement about the relationship between two or more things that needs to be examined" [40].

\subsubsection{Hypothesis 1}

To respond productively to rapid change, a company must "be aware of new information generated in its environment and adopt structures that enable fast decision making and practices that reduce information overload [14]. For this reason, companies are investing heavily in information technologies to enhance their ability to manage information and knowledge across the supply chain. [15].

Information technologies play a central role in SCM. They enable companies to collect, analyze and disseminate information among members of the chain to improve decision making. Connecting managers across functional and organizational boundaries and providing them with relevant, accurate and timely information reduces temporal and spatial distance enabling them to make better, more collaborative decisions. Recent technological advancements have dramatically increased companies' ability to connect. The goal of enabling individuals anywhere in the chain to seamlessly interact with one another is becoming a technological possibility.

Connectivity creates the capability to share information. However, people make the decisions regarding what will be shared and when. A company's willingness to share information- that is, its openness to sharing relevant information honestly and frequently- ultimately determine the extent of sharing that takes place [14]. Huge investments in technology can be negated by an unwillingness to share needed information.

Organizational theory suggests that company culture influences how willing its people are to share 
information. This cultural influence holds for sharing across internal functions such as marketing and engineering as well as across organizations in the chain. Indeed, each organization may have a different attitude toward information sharing. Mangers can influence the level of information sharing by supporting programs that enable individuals to develop initiatives and opportunities of sharing. To justify investments in information sharing, it is important to determine whether a verifiable relationship exists between information sharing and performance. The need to examine this relationship leads to our first hypothesis:

H1: Information sharing is positively correlated to a company's performance.

\subsubsection{Hypothesis 2}

Modern organization management theory suggests that decentralizing decision rights is an effective way of managing a large organization. To make timely decisions effectively, decision rights should be assigned to the person is just at the decision spot and has specialized knowledge of his or her surroundings. One problem of decentralized control is, however, the whole system may not achieve the optimum performance even though each member optimizes its performance. A "broken" supply chain will have substantial stock held one site to enable another site's stock reduction. This deficiency caused by decentralized control has led to the evolution of the partnership relations between buyers and suppliers. Therefore, it is expected that if each member of the SC has more information about other members then they treats each other as strategic partner.

Among existing quantitative studies of information sharing and supply chain partnerships, Iyer and Bergen [41] examined the impact of quick response (QR) on fashion apparel industry. Baganha and Cohen [42] presented a hierarchical model as an analytical framework to examine the stabilizing effects of inventories in supply chains. EDI implementation can incorporate information flow between a supplier and a buyer, which will benefit a dyadic supply chain relationship [43]. However, there exists a large amount of literature on the concepts of supply chain partnerships projecting extremely optimistic views about their promise as win-win partnerships without rigorous analysis to support the cause of optimism.

With its origin in lean supply, information (cost) transparency was originally introduced as: "The sharing of costing information between customer (buyer) and supplier, including data which would traditionally be kept secret by each party, for use in negotiations. The purpose of this is to make it possible for customer and supplier to work together to reduce costs (and improve other factors). Information transparency is of no value unless it is two-way. It was proposed that the information sharing must be reciprocal, selective and justified- but not necessary symmetrical. It was central to the initial conceptualization that transparency should go beyond simply better "communication". Underlying the concept is the joint sharing or pooling of risk. This pooling of risk fundamentally distinguishes transparency (i.e. "two-way" or "reciprocal" sharing) from customer driven approaches. The risk taken on by supplier in revealing sensitive information might be balanced by a similar advance by the customer. In this way, within a carefully bounded arena, the parties to the transaction become interdependent- for simple commercial reasons on both parts and not as part of any philosophical standpoint (such as espoused partnering). To justify investments in information sharing, it is important to determine whether a verifiable relationship exists between information sharing and supplier-buyer relationship. The need to examine this relationship leads to our second hypothesis:

H2: Information sharing promotes partnership and trust based relationship

\subsubsection{Hypothesis 3}

Information or intelligence comes into an organization in many formats - paper, internet, television, radio. Each person who uses that information will process it differently depending on their preference for receiving information, learning and communication combined with their values and previous knowledge. The information becomes personal knowledge as critical thinking processes of analysis, evaluation, review and reflection are applied. As tacit internalized knowledge it may be expressed in action but the chain may not be benefited from this new insight.

Knowledge sharing is defined as transferring knowledge to others within the organization by individual's efforts. Evolutionary psychology supports the notion that people have developed tendencies to share with others. Some previous studies found people were socially programmed to cooperate when they solve problems, develop expectations regarding others' behavior through group communications and actions. 
Developing knowledge in the supply chain is a participative process for no one person in a climate of discontinuity can have all the solutions. Hierarchical structures tend to silo knowledge and discourage sharing. Opposite to this are bottom-up groups of interest or communities of practice established around a common interest and co-ordinate across the chain. These groups bring together implicit and explicit knowledge from a range of perspectives. They are a means of mentoring new members in a supportive learning culture with regard to the business strategy and how they can contribute.

The quality and relevance of the initial information that flows into an organization has a direct impact on the knowledge developed from its use. Information needs to be both timely and relevant to the context of the business. A toolbox of information and communication skills is used when accessing, using, evaluating and applying information. People working together with contextual information develop competence in knowing how and when to use these skills which impact on the way in which knowledge is developed. The need to check the relationship between information sharing and knowledge sharing leads to third hypothesis:

H3: Information sharing has a positive effect on knowledge sharing

\subsubsection{Hypothesis 4}

In business-to-business relationships, several conditions that make exchange processes difficult must be managed. The most important characteristics of buyer-supplier relationships are the different cultures of the business partners, their communication problems and technological distances. Technological distances have largely been ignored in the extant literature but are important in the consideration of buyer-supplier relationships. If the product technologies and specifications in different organizations are distinct, (technological distance or knowledge gap between buyer and supplier), the buyer must become acquainted with other standards when collaborating with a supplier.

Recently, knowledge-sharing with supply chain members, i.e., with suppliers and customers, has received increasing research attention. For example, Dyer and Singh [44] suggest in their conceptual work that learning and knowledge play a significant role in inter-firm buyer-supplier relationships. Andersen and Christensen [45] discuss a conceptual model of inter-partner learning processes in supply chains and extend the model through a single case study. In the case study involving a customer as the main contractor in a construction project with 30 suppliers, $\mathrm{Ha}{ }^{\circ}$ kansson et al. [46] revealed that firms learn best when their customer relationship is embedded in a network. The development of Toyota's knowledge-sharing with suppliers and among its supplier network has been presented in several in-depth case studies. However, research to date has been primarily of a conceptual or qualitative nature. Bessant [47] remark that, in the face of "the potential which supply chains offer for enabling learning, there is, as yet, little research-based information on the topic." In view of the potential advantages of sharing knowledge with suppliers and customers, and considering the predominantly prescriptive nature of the research and the lack of empirical research, it seems quite clear that research on this phenomenon should be expanded.

The value of knowledge may influence one's willingness to share said knowledge. The psychology literature suggests a negative relationship between value and sharing. However, this depends upon the sharer losing all or part of the value of the object as a result. Since the sharer of knowledge may not lose value from the act of sharing, then a different relationship may hold true for knowledge sharing (e.g., a positive relationship or a curvilinear relationship where an individual is more willing to share their knowledge as its value increases up to a point). Until we better understand how people determine the value of their knowledge and the impact on what knowledge people are willing to share, the relationship between values and sharing is difficult to predict and warrants further investigation.

Learning and sharing knowledge with suppliers play an important role in inter-firm buyer-supplier relationships. Suppliers may possess resources that complement those of the focal firm. This may generate positive externalities and allow the firm to capture spillover from its suppliers. Research has documented the benefits of knowledge-sharing networks in which suppliers are involved. For manufacturing firms, long-term, cooperative relationships with suppliers can provide a unique capability that establishes a source of competitive advantage. Thus, the hypothesis is as follows:

H4: Knowledge sharing promotes partnership and trust based relationship 


\subsubsection{Hypothesis 5}

Knowledge is the competitive advantage in a supply chain - it not only transforms the production but also the ability to foresee and manage complexity and change. The challenge is to create a value chain where people have the necessary skills to add value by developing, acquiring, exploring, sharing and applying knowledge - not just to resolve issues but to be innovative. Knowledge acquisition and application within the supply chain underpin the intellectual capital of the chain and its ability to ensure a competitive product and increased profit margin [4].

The 'value' in a value chain resides within the flow of thinking processes throughout the chain. The power to drive innovation within the chain lies within the people rather than the technology. The degree of value placed upon the acquisition and application of knowledge underlies the chain's ability to foresee and manage complexity and change. A wise supply chain engenders a climate of knowledge growth and acquisition as part of its business strategy realizing that the decision making capacity of the people within the chain creates the value for the client.

In this segment of the study the focus is on the transfer of knowledge that exists in the form of 'knowhow' rather than on the transfer of knowledge that exists in the form of 'operational information'. The greater we will focus on knowledge sharing, greater will the knowledge management effectiveness in improving the enterprise system performance. This study also suggests that buyers typically can focus on dissemination of new knowledge and knowledge advancements. Similarly the supplier can focus on knowledge acquisition, knowledge adaptation and knowledge application. The synergy between buyer and supplier through concurrent thinking is important. Each member of the supplier-buyer relationship is an autonomous body that takes knowledge decisions motivated by self-optimization at the local level. Due to a clear lack of collaborative-knowledge sharing and associated concurrency, such decisions often become counterproductive. So, we propose the following hypothesis:

H5: The level of knowledge-sharing with suppliers positively influences performance.

\subsubsection{Hypothesis 6}

Partnerships are characterized by closer contacts and are sometimes embedded in manufacturers' singlesourcing strategies. A long-term perspective is a pre- requisite for a higher degree of integration among partners and greater level of information exchange. Purchasing managers became information brokers as they form the interface between the manufacturers' site and their supplier base [5].

Dwyer et al. [33] describes a continuum of different types of buyer-supplier relationships. They believe that firms engage in cooperative buyer-supplier relationships because the firms expect to benefit from the relationship. Only as long as the firms perceive a benefit from the relationship do they continue in the cooperative buyer-supplier relationship. Japanese auto firms cultivate their suppliers through investments, sharing of knowledge, and joint problem solving. As a result, suppliers search for ways to meet the needs of the buying firm's product design and development; and, the better suppliers seek to create value for the buying firms. Noordewier et al. [34], state that purchasing performance is an important determinant of a firm's competitiveness. Their empirical research shows that long-term cooperative agreements have a positive impact on purchasing performance in terms of acquisition cost when the level of uncertainty is relatively high. However, long-term cooperative agreements have no effect on performance when the level of uncertainty is relatively low. Establishing long-term relationships with the key suppliers can lead to improved firm's financial performance [35]. According to Larson [36], purchasing coordination of the firm's activities with key suppliers can impact total costs. As demonstrated by the Ford Motor's use of long-term buyer-supplier relationships to help achieve a competitive advantage in the automobile industry. Under total quality management (TQM), Ford transformed buyer-supplier relationships from adversarial to cooperative. Ford's success demonstrates that businesses can increase their competitiveness by implementing cooperative supplier relationships [37]. All of the literatures were highlighted on the buying firm's performance. No research work was performed on the performance from the supplier's perspective.

The open sharing of information helps reduce uncertainty by allowing customers insights into the supplier's future plans. For example, early information about changes in a supplier's product line enables the customer to make timely changes in acquisition and operational procedures, thus avoiding costly crash programs. Furthermore, knowledge provided by supplier's can enable the customer to make better use of the product purchased, which lowers costs and increases benefits. In addition, the exchange of infor- 
mation sets the stage for closer cooperation. Intensive communication is also prerequisite for building trust, which in turn positively affects performance.

We define a buyer-supplier relationship, or partnership, as the set of practices and routines that support economic exchanges between the two firms. A buyer-supplier link refers to the fact that the two firms have been doing business continuously for a given period of time. A supplier's operational performance refers to the combination of on-time delivery, perfect order fulfillment rate, delivery reliability/ dependability, quality (ability to meet specifications), speed of response and manufacturing capability (e.g, capacity). We consequently propose the following:

H6: Buyer-supplier partnership relationship has positive influence on Suppliers performance.

\section{RESEARCH METHODOLOGY}

The purpose of this study is to investigate (1) the link between information sharing with supplier on company's performance (2) the relationship between information sharing and supplier-buyer relationship, (3) the effect of information sharing on knowledge sharing, (4) the influence of knowledge sharing on supplier-buyer relationship (5) the effect of knowledge sharing on firms performance and (6) the impact of supplier-buyer relationship on supplier performance. The primary research instrument for the study is a rigorously validated questionnaire. A summary of the survey questions is shown with the summary statistics in Table 1.

Table 1: Survey questions and descriptive statistics

\begin{tabular}{|c|c|c|}
\hline Survey Questions & Mean & S. D. \\
\hline \multicolumn{3}{|c|}{$\begin{array}{l}\text { How often does your major customer provide your firm with its information in the following dimensions }[1= \\
\text { never, } 2=\text { annually, } 3=\text { semi-annually, } 4=\text { quarterly, } 5=\text { monthly, } 6=\text { weekly, } 7=\text { daily }]\end{array}$} \\
\hline Price & 4.13 & 1.570 \\
\hline Quality & 4.73 & 1.639 \\
\hline Changes in purchase order information & 4.60 & 1.545 \\
\hline Planned order information & 4.80 & 1.400 \\
\hline Inventory level information & 4.73 & 1.721 \\
\hline Product specifications & 5.13 & 1.074 \\
\hline Design drafts and sketches & 4.77 & 1.431 \\
\hline Performance evaluation information & 3.33 & 1.709 \\
\hline Future demand forecasting information & 3.77 & 1.223 \\
\hline Production planning information & 5.03 & 1.245 \\
\hline Negotiation records, contracts & 4.17 & 1.315 \\
\hline Confirmation of orders & 5.23 & 0.898 \\
\hline \multicolumn{3}{|c|}{$\begin{array}{l}\text { How often does your major customer provide your firm with its (knowledge based) information in the followin } \\
\text { dimensions }[1=\text { never, } 2 \text { = annually, } 3=\text { semi-annually, } 4=\text { quarterly, } 5=\text { monthly, } 6=\text { weekly, } 7=\text { daily] }\end{array}$} \\
\hline Organizational philosophy & 2.53 & 1.224 \\
\hline Skills, suggestions, ideas, expertise & 3.77 & 1.755 \\
\hline Markets trend & 3.20 & 0.997 \\
\hline Problems (including personal issues) & 5.10 & 1.845 \\
\hline New business directions and new scenarios & 3.23 & 1.455 \\
\hline Changes in product and process designs & 4.37 & 1.732 \\
\hline \multicolumn{3}{|c|}{$\begin{array}{l}\text { The following questions relate to the relationship with your customer firm. Please indicate your opinion on } \\
\text { the following dimensions }[1=\text { strongly disagree, } 2=\text { disagree, } 3=\text { apparently disagree, } 4=\text { not completely } \\
\text { disagree, } 5=\text { apparently agree, } 6=\text { agree, } 7=\text { significantly agree }]\end{array}$} \\
\hline
\end{tabular}




\begin{tabular}{|c|c|c|}
\hline $\begin{array}{l}\text { We enter into special agreements with customer relationships who have } \\
\text { judged our improved performance. }\end{array}$ & 5.27 & 1.530 \\
\hline We are loyal to key customers. & 5.97 & 1.217 \\
\hline $\begin{array}{l}\text { We have very frequent face-to-face planning/communication with key } \\
\text { customers. }\end{array}$ & 5.73 & 1.048 \\
\hline $\begin{array}{l}\text { There is high corporate level communication on important issues with key } \\
\text { customers. }\end{array}$ & 5.77 & 1.251 \\
\hline There are direct computer to computer links with key customers. & 4.87 & 2.030 \\
\hline \multicolumn{3}{|c|}{$\begin{array}{l}\text { The following questions relate to the relationship with your supplier firm. Please indicate your opinion on the } \\
\text { following dimensions }[1=\text { strongly disagree, } 2=\text { disagree, } 3=\text { apparently disagree, } 4=\text { not completely disagree, } \\
5=\text { apparently agree, } 6=\text { agree, } 7=\text { significantly agree] }\end{array}$} \\
\hline $\begin{array}{l}\text { We enter into special agreements with supplier's relationships who have } \\
\text { judged our improved performance. }\end{array}$ & 5.43 & 1.223 \\
\hline We are loyal to key suppliers. & 5.23 & 1.612 \\
\hline $\begin{array}{l}\text { We have very frequent face-to-face planning/communication with key } \\
\text { suppliers. }\end{array}$ & 5.53 & 1.196 \\
\hline $\begin{array}{l}\text { There is high corporate level communication on important issues with key } \\
\text { suppliers. }\end{array}$ & 5.57 & 1.331 \\
\hline There are direct computer to computer links with key suppliers. & 4.90 & 2.295 \\
\hline \multicolumn{3}{|c|}{$\begin{array}{l}\text { The following questions relate to the performance of your supplier firm. Please indicate your opinion on the } \\
\text { following dimensions }[1=\text { significantly poor, } 2=\text { poor, } 3=\text { apparently poor, } 4=\text { between poor and good, } 5= \\
\text { apparently good, } 6=\text { good, } 7=\text { significantly good }]\end{array}$} \\
\hline On-time delivery & 5.40 & 0.770 \\
\hline Perfect order fulfillment rate & 5.17 & 1.053 \\
\hline Delivery reliability/dependability & 5.30 & 1.149 \\
\hline Quality (e.g., ability to meet specifications) & 5.67 & 0.922 \\
\hline Speed of response & 5.43 & 0.858 \\
\hline Manufacturing capability (e.g., capacity) & 5.53 & 1.167 \\
\hline
\end{tabular}

\subsection{Instrument Design and Data Collection}

The study involves two data collection stages: pilot survey and formal survey. The pilot survey is designed to test the viability of the study and purify the data collection instrument. Four academic researchers and three industry executives critiqued the research instrument for relevance and clarity. The questionnaire for the main study was refined based on feedback from the pilot study. The study includes a wide variety of manufacturing industries. A total of 105 surveys were sent (interviewed and mailed). Few questionnaires were mailed due to insufficient stipulation for interview. Among 105 sent questionnaire 44 returned. Few questionnaires were mailed due to insufficient stipulation for interview. No difference was found between the interviewed and mailed question- naire. For the clarification of the mailed questionnaires the concerned person was informed via telephone calls. Among the returned 44 survey only 30 were in usable format. The response rate was approximately $42 \%$. For normal distribution the minimum sample size requirement is 30 . The data analysis is based on the 30 useable questionnaires.

\subsection{The Sample List}

The data represents a cluster of Garments Industries those have started to use modern technologies of information sharing. The sample list consisted of individuals at decision-making levels, and in strategically oriented positions. The targeted respondents were senior executives (i.e. Vice President, Director, General Manager, Assistant General Manager, 
Plant Manager, Production Manager, Merchandising Manager, Industrial Engineering Executives and Managers). The average number of employees in the respondents' firms was about 5000. Eight companies had more than 10,000 employees. To test the nonresponse bias, the responses of those who returned early were compared with those who returned late to determine if there are any statistical differences [48]. There were no statistical differences between the early and late responses.

\subsection{Measurement Scales}

Descriptive statistics for each survey statement are presented in Table 1. Each statement required responses based on a 7-point Likert scale [49]. There are five variables: information sharing, Knowledge based information sharing, supplier's relationship with buyer, Buyers relationship with supplier, Supplier Performance. Among the five variables information is the only independent variable. Knowledge and relationship are acting as an independent variable and also as a dependent variable. The performance of the supplier is always the dependent variables.

\subsection{Validity and Reliability of Measurement Scales}

The validation process for the survey instrument had three steps: content validity; construct validity, and reliability [50]. The literature review and in-depth interviews conducted with business executives and researchers established the basis of content validity for the survey instrument. The purpose of construct validity is to show that the items measure what they purport to measure. Uni-dimensionality was established with exploratory factor analysis, where 0.30 is generally considered to be the lowest significant factor loading to define the construct [50]. The internal consistency in this study is measured by Cronbach's alpha. The lower limit of 0.6 is considered acceptable for newly developed scales and 0.7 for established scales [51]. Cronbach's coefficient alphas were calculated for the items of each survey construct. The results of the measurement scales are shown in Table 2.

Table 2: Results of measurement validation

\begin{tabular}{|c|c|c|c|}
\hline Scale name & Variable name & $\begin{array}{l}\text { Factor } \\
\text { loading }\end{array}$ & Scale statistics \\
\hline \multirow{11}{*}{ Information Sharing } & Info Q1 & 0.420 & \multirow{11}{*}{ Cronbach's alpha: 0.762} \\
\hline & Info Q2 & 0.742 & \\
\hline & Info Q3 & 0.616 & \\
\hline & Info Q4 & 0.738 & \\
\hline & Info Q5 & 0.708 & \\
\hline & Info Q6 & 0.384 & \\
\hline & Info Q7 & 0.451 & \\
\hline & Info Q8 & 0.553 & \\
\hline & Info Q9 & 0.425 & \\
\hline & Info Q10 & 0.662 & \\
\hline & Info Q11 & 0.357 & \\
\hline \multirow{6}{*}{$\begin{array}{l}\text { Knowledge Based } \\
\text { Information Sharing }\end{array}$} & Know Q1 & 0.677 & \multirow{6}{*}{ Cronbach's alpha: 0.757} \\
\hline & Know O2 & 0.681 & \\
\hline & Know Q3 & 0.620 & \\
\hline & Know Q4 & 0.795 & \\
\hline & Know Q5 & 0.571 & \\
\hline & Know Q6 & 0.707 & \\
\hline \multirow{10}{*}{$\begin{array}{c}\text { Relationship(From } \\
\text { Supplier's perspective }+ \\
\text { From Buyer's perspective }\end{array}$} & Rel Q1 & 0.731 & \multirow{10}{*}{ Cronbach's alpha: 0.785} \\
\hline & Rel Q2 & 0.474 & \\
\hline & Rel Q3 & 0.641 & \\
\hline & Rel Q4 & 0.532 & \\
\hline & Rel Q5 & 0.460 & \\
\hline & RelQ6 & 0.825 & \\
\hline & RelQ7 & 0.567 & \\
\hline & RelQ8 & 0.656 & \\
\hline & RelO9 & 0.695 & \\
\hline & RelQ10 & 0.510 & \\
\hline \multirow{6}{*}{$\begin{array}{l}\text { Performance (Supplier } \\
\text { Performance) }\end{array}$} & Perf Q1 & 0.784 & \multirow{6}{*}{ Cronbach's alpha: 0.803} \\
\hline & Perf Q2 & 0.726 & \\
\hline & Perf Q3 & 0.828 & \\
\hline & Perf Q4 & 0.724 & \\
\hline & Perf Q5 & 0.467 & \\
\hline & Perf Q6 & 0.728 & \\
\hline
\end{tabular}




\section{PATH ANALYSIS AND RESULTS}

The beginning is by drawing a path diagram of a simple multiple regressions, as shown in Figure 2. In the figure 2, information sharing and knowledge sharing are predictor variables and that the performance is the outcome, but relationship is both a dependent and independent variable. It's the outcome (dependent variable) with respect to the information and knowledge sharing, but it's the predictor (independent variable) for performance. That is the variable 1 (i.e information sharing) is exogenous. Variable 2, 3 and 4 (knowledge sharing, relationship and performance) are endogenous. The $\mathrm{P}_{\mathrm{ij}}$ represents path coefficients predicting variable i from variable $j, e_{i}$ represents errors or residuals for variable $i$ [52].

Assuming, $\mathrm{F}_{1}=$ Information, $\mathrm{F}_{2}=$ Knowledge, $\mathrm{F}_{3}=$ Relation and $\mathrm{F}_{4}=$ Performance

$\mathrm{F}_{1}=\mathrm{e}_{1}$

$\mathrm{F}_{2}=\mathrm{P}_{21} \mathrm{~F}_{1}+\mathrm{e}_{2}$

$\mathrm{F}_{3}=\mathrm{P}_{31} \mathrm{~F}_{1}+\mathrm{P}_{32} \mathrm{~F}_{2}+\mathrm{e}_{3}$

$\mathrm{F}_{4}=\mathrm{P}_{41} \mathrm{~F}_{1}+\mathrm{P}_{42} \mathrm{~F}_{2}+\mathrm{P}_{43} \mathrm{~F}_{3}+\mathrm{e}_{4}(4)$
Estimated equations are:

$$
\begin{aligned}
& \hat{F_{2}}=P_{21} F_{1} \\
& \hat{F_{3}}=P_{31} F_{1}+P_{32} F_{2} \\
& \hat{F_{4}}=P_{41} F_{1}+P_{42} F_{2}+P_{43} F_{3}
\end{aligned}
$$

Estimated path coefficients from multiple regression analyses:

$\mathrm{P}_{21}=0.424$

$P_{31}=-0.000015$

$\mathrm{P}_{32}=0.166$

$\mathrm{P}_{41}=-0.313$

$\mathrm{P}_{42}=0.261$

$\mathrm{P}_{43}=0.536$

Figure 2: Information sharing, knowledge sharing, Relationship and Performance

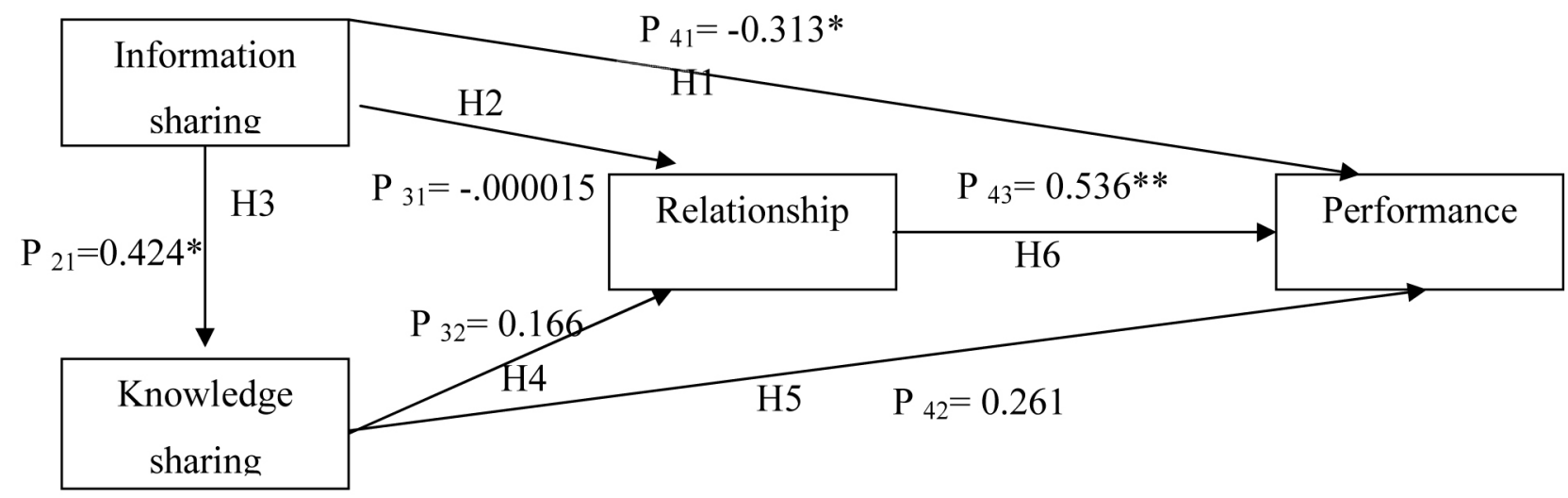

** indicates significance at $\mathrm{p}<0.05$ and ${ }^{*}$ indicate significance at $\mathrm{p}>0.05$

These tests-looking at the signs of the path coefficients and their significance levels-tell us about the individual component of the model. We can also look at the model as a whole, with a $\mathrm{R}^{2}$ value. The value of $\mathrm{R}^{2}$; the bigger the better and at the same time the significance level should be checked.

Firstly considering the model of information and knowledge, information here is the predictor/ independent variable and knowledge is the dependent variable. The result of table 3 and 4 shows a value of $R^{2}=0.180$ and the result is significant at $p<$ 0.05 level. It indicates that the dependent variable knowledge is $18 \%$ represented by the independent variable information and in this case the representation of the variance of the dependent variable is not 
remarkable. In case of $\mathrm{R}^{2}$ value the bigger the better means that the independent variable is better capable to represent the variance of the dependent variable.

Table 3: Model Summary (for independent variable information)

\begin{tabular}{|c|c|c|c|c|c|c|c|c|c|}
\hline \multirow[b]{2}{*}{ Model } & \multirow[b]{2}{*}{$\mathrm{R}$} & \multirow[b]{2}{*}{$\begin{array}{c}\mathrm{R} \\
\text { Square }\end{array}$} & \multirow[b]{2}{*}{$\begin{array}{l}\text { Adjusted } \\
\text { R Square }\end{array}$} & \multirow[b]{2}{*}{$\begin{array}{l}\text { Std. Error of } \\
\text { the Estimate }\end{array}$} & \multicolumn{5}{|c|}{ Change Statistics } \\
\hline & & & & & $\begin{array}{c}\mathrm{R} \\
\text { Square } \\
\text { Change }\end{array}$ & F Change & df1 & df2 & Sig. F Change \\
\hline 1 & $0.424(a)$ & 0.180 & 0.150 & 0.92176459 & 0.180 & 6.132 & 1 & 28 & 0.020 \\
\hline
\end{tabular}

(a) Predictors: (Constant), Information

Table 4: ANOVA (for dependent variable Knowledge and information is the independent Variable)

\begin{tabular}{|c|c|r|r|r|r|c|}
\hline Model & & Sum of Squares & df & Mean Square & F & Sig. \\
\hline 1 & Regression & 5.210 & 1 & 5.210 & 6.132 & $0.020(\mathrm{a})$ \\
\hline & Residual & 23.790 & 28 & 0.850 & & \\
\hline & Total & 29.000 & 29 & & & \\
\hline
\end{tabular}

(a) Predictors: (Constant), Information, and Dependent Variable: Knowledge

Secondly considering the model of information sharing, knowledge sharing, buyer-supplier relationship and supplier's performance, the value of $\mathrm{R}^{2}$ here is 0.406 and the model is significant at $\mathrm{p}<0.05$ level. This means that the independent variables information, knowledge and relationship are significantly capable to represent the variance of the dependent variable performance. Thus, the model is validated. The independent variables are explaining the $40.6 \%$ variance of the dependent variable.

5.1 Comparison of Actual and Reproduced Correlation

To test whether the model fits the data compared to actual correlations to reproduced correlations based on paths in the model, we denote actual correlation by ' $\mathrm{r}$ ' and reproduced correlation by ' $\mathrm{r}$ ' the actual correlations are in bracket below.

$$
\begin{aligned}
\mathrm{r}_{12}^{*} & =\mathrm{P}_{21}(\mathrm{DE})=0.424(0.424) \\
\mathrm{r}_{13}^{*} & =\mathrm{P}_{31}(\mathrm{DE})+\mathrm{P}_{32} \mathrm{P}_{21}(\mathrm{IE}) \\
& =-0.000015+0.166^{*} 0.424
\end{aligned}
$$

$$
\begin{aligned}
& =0.070384(0.070) \\
& \mathrm{r}_{14}^{*}=\mathrm{P}_{41}(\mathrm{DE})+\mathrm{P}_{42} \mathrm{P}_{21}(\mathrm{IE})+\mathrm{P}_{43} \mathrm{P}_{31}(\mathrm{IE})+\mathrm{P}_{43} \mathrm{P}_{32} \mathrm{P}_{21} \\
& \text { (IE) } \\
& =-0.313+0.261^{*} 0.424+0.536^{*}(-0.000015)+ \\
& 0.536^{*} 0.166^{*} 0.424 \\
& =-0.165(-0.165) \\
& \mathrm{r}_{23}^{*}=\mathrm{P}_{31} \mathrm{P}_{21}(\mathrm{~S})+\mathrm{P}_{32}(\mathrm{DE}) \\
& =0.166(0.166) \\
& \mathrm{r}_{24}^{*}=\mathrm{P}_{41} \mathrm{P}_{21}(\mathrm{~S})+\mathrm{P}_{42}(\mathrm{DE})+\mathrm{P}_{43} \mathrm{P}_{31} \mathrm{P}_{21}(\mathrm{~S})+\mathrm{P}_{43} \mathrm{P}_{32} \\
& \text { (IE) } \\
& =0.217(0217) \\
& \mathrm{r}_{34}^{*}=\mathrm{P}_{41} \mathrm{P}_{31}(\mathrm{~S})+\mathrm{P}_{41} \mathrm{P}_{32} \mathrm{P}_{21}(\mathrm{~S})+\mathrm{P}_{42} \mathrm{P}_{31} \mathrm{P}_{21}(\mathrm{~S})+\mathrm{P}_{42} \mathrm{P}_{32} \\
& (\mathrm{~S})+\mathrm{P}_{43}(\mathrm{DE}) \\
& =0.557(0.557)
\end{aligned}
$$

In this conceptual model the reproduced and original correlations have the same value. i.e. this model has all possible paths among the variables and hence no path deleted. 


\subsection{Results and Findings}

The developed hypotheses have some significant characteristics. The features need to be highlighted. The results of each hypothesis are discussed in details.

\subsubsection{Findings related to Hypothesis 1}

It was hypothesized that Information sharing is positively correlated to a company's performance (Hypothesis 1). The result of the study suggests that Hypothesis 1 is not supported as shown by the standardized coefficient of -0.313 in figure 2 . The value of path coefficient doesn't support the hypothesis. The value is significant at the $\mathrm{p}>0.05$ level.

\subsubsection{Findings related to Hypothesis 2}

It was hypothesized that Information sharing promotes partnership and trust based relationship (Hypothesis 2). The results of the study suggest that Hypothesis 2 is not supported (i.e. information Sharing doesn't promote relationship) as shown by the standardized coefficient of -0.000015 for H2 in Figure 2 and the result is insignificant. This may be due to small sample size for this particular type of analysis.

\subsubsection{Findings related to Hypothesis 3}

It was hypothesized that Information sharing has a positive effect on knowledge sharing (Hypothesis 3 ). The result of the study suggest that Hypothesis 3 is strongly supported (i.e. information sharing influences knowledge sharing) as shown by the standardized path coefficient of 0.424 and the value is significant at $\mathrm{p}<0.05$ level. This result provides empirical evidence for enabling effect of information sharing on knowledge sharing. The result ensures that as the level of information sharing between buyer and supplier increases, it promotes the knowledge sharing. Information was categorized as day to day operational information and knowledge as the know-how. So, it supports the previous literature (i.e Information becomes knowledge through critical and creative thought processes) [17].

\subsubsection{Findings related to Hypothesis 4}

Hypothesis 4 was that Knowledge sharing promotes partnership and trust based relationship. The results of the study suggest that Hypothesis 4 is weakly supported as shown by the path co-efficient of 0.166 but the value is insignificant. The insignificance of the data may be due to the small sample size (unfortunately only 30 usable data were obtained). But it is evident from the result that there is a link between the sharing of knowledge with supplier-buyer relationship.

\subsubsection{Findings related to Hypothesis 5}

The level of knowledge-sharing with suppliers positively influences performance (Hypothesis 5). The results of the study suggest that Hypothesis 5 is weakly supported as shown by the path co-efficient of 0.261 but the value is insignificant. The insignificance of the data may be due to the small sample size (unfortunately only 30 usable data were obtained). It is evident from the result that knowledge sharing influences performance better than information sharing. In case of the linkage of information sharing and performance a negative relationship was obtained but the result is positive for knowledge sharing,

\subsubsection{Findings related to Hypothesis 6}

Buyer-supplier partnership relationship has positive influence on Suppliers performance (Hypothesis 6). The result of the study suggest that Hypothesis 6 is strongly supported (i.e. Buyer-supplier partnership relationship has positive influence on Suppliers performance) as shown by the standardized path coefficient of 0.536 and the value is significant at $p<0.05$ level. Though the previous research has emphasized on buyer-supplier's relationships effect on buying firms performance but from the result of the conceptual model it is evident that buyer-supplier relationship (partnership relationship) not only affects the buying firm's performance but also the supplying firms performance.

\subsection{Regression Models and Results}

Regression analysis is used to test the influence of information sharing and knowledge sharing on relationship and on performance and then identifying the influence of supplier-buyer relationship on supplier's operational performance. The correlation is shown in the correlation Table 5. 
Table 5: Correlation Table

\begin{tabular}{|l|l|l|l|l|}
\hline & Information (F1) & Knowledge (F2) & Relationship (F3) & Performance (F4) \\
\hline Information (F1) & 1.00 & $0.424^{* *}$ & 0.070 & -0.165 \\
\hline Knowledge (F2) & & 1.00 & 0.166 & 0.217 \\
\hline Relationship (F3) & & & 1.00 & $0.557 * *$ \\
\hline Performance (F4) & & & & 1.00 \\
\hline
\end{tabular}

** Indicates significance at $\mathrm{p}<0.05$ and * indicate significance at $0.05<\mathrm{p}<0.10$

From the correlation table 5 it is clear that information sharing has a strong correlation with knowledge sharing and the $\mathrm{p}$-vale is also significant within $\mathrm{p}<$ 0.05. Also information sharing has a weak relationship with buyer-supplier partnership relationship but the $p$-value is insignificant. The effect of information sharing on performance is negative. This is the thinking of the buying or manufacturing firm of Bangladesh readymade Garments Industries.

It is also evident from the correlation table that knowledge sharing also has an impact on buyersupplier relationship though the correlation is weak. Knowledge sharing with supplier firm influences the performance of the buying firms.

The most significant and strong correlation was obtained between supplier-buyer partnership relation with suppliers performance. The previous studies have argued that buyer-supplier partnership relation influences the buying firm's performance. But from the study we have performed it is evident that buyer-supplier close relationship/ contact also influence the supplier's operational performance.

\section{CONCLUSIONS}

The previous research works have considered the individual effect of information and knowledge sharing on supplier's operational performance. The aim of the study was to identify the combined effect of information and knowledge sharing on supplier's operational performance. The supplier's performance linkage with supplier-buyer relationship has been discussed. The effect of knowledge and information sharing on performance via supplier-buyer partnership based relationship has also been considered. In regards to the present analysis following conclusions can be drawn:

The information sharing with key supplier does not affect the supplier's operational performance. This is due to the fact that few companies understand how to turn operational or knowledge based information sharing into a competitive advantage. The interviews and mail survey confirmed that most companies yet to leverage combined information support technology and willingness strategy. Processes needed to be redesigned to take advantage of new capabilities made possible by the technology.

The information sharing with supplying firm has a very weak linkage with supplier-buyer relationship. This is due to the inaccuracy, late response of relevant information. That is the right information is not shared at the right time.

The information sharing with supplier promotes knowledge sharing. This is the reflection of the previous literature. If there is a continuous flow of information like quality, price, future demand forecasting information, the buyer is then interested to share information like organizational philosophy, future market trend, and the new market directions with their supplier.

The knowledge sharing with key supplier does not have a strong linkage with supplier-buyer relationship. The reason for this sort of outcome indicates that the supplying firms are not capable to utilize the knowledge based information effectively and efficiently.

The knowledge sharing with the supplier has a weak positive relationship with supplier's operational performance. This was the representation of the previous literature. That is if the markets trend and problem solving procedure relevant information is shared with the supplier then it ultimately develops keenness in supplier. The buyer's interest on supplier promotes the operational performance of the supplier. That is the supplier ensure the quality, responds to the buyer's need rapidly and confirm on-time delivery. 
Finally, the buyer-supplier relationship has a strong influence on supplying firm's performance. As pervious literature highlighted the effect of buyersupplier close contact or partnership relationship and its positive impact on buying firms operational performance, the result of supplying firm's performance is a further addition to previous work. The result indicates that if there is a close dyadic relationship between the buyer/ manufacturer and supplier, the supplier's response to buying firms needs is improved.

\section{REFERENCES}

Zhou, H. and Benton, Jr. W.C. (2007) "Supply chain practice and information sharing", Journal of Operations Management, Vol. 25, pp. 1348-65

Fawcett S. E., Osterhaus P., Magnan G., Brau J. C. and Mc Carter M. W., (2007) "Information sharing and supply chain performance: the role of connectivity and willingness", Journal of Supply Chain Management, Vol. 12, No. 5, pp. 358-368

Wadhwa, S. and Saxena, A. (2005), "Knowledge Management based Supply Chain: An Evolution Perspective", Global Journal of e-Business and Knowledge Management, Vol. 2, No.2, pp.13-29

Hart D. (2004), “The Wise Supply Chain: Knowledge as a component of its success", In: Proceedings $13^{\text {th }}$ Biennial Conference of Australian Rangeland Society, Alice Springs, NT, PP. 154-60

Szwejczewski, M., Lemke, F. and Goffin, K. (2005),"Manufacturersupplier relationships: An empirical study of German manufacturing companies", International Journal of Operations and Production Management, Vol.25, No. 9, pp. 875-897

Ellram, L.M. (1991), "Life-cycle patterns in industrial buyer-seller partnerships", International Journal of Physical Distribution \& Logistics Management, Vol. 21 No. 9, pp. 12-21

Neumann, S., Segev, E. (1979), “A case study of user evaluation of information characteristics for systems improvement", Journal of information and Management, Vol. 2, pp. 271-278

McCormack, K., 1998. What Supply Chain Management Practices Relate to Superior Performance? DRK Research Team, Boston, MA

Petersen, K. (1999), “The effect of information quality on supply chain performance: an inter-organizational information system perspective", Unpublished dissertation. Michigan State University, MI

Vijayasarathy, L., Robey, D., 1997. The effect of EDI on market channel relationship in retailing. Information and Management 33 (2), 73-86.

Sum, C., Yang, K., Ang, J., Quek, S., 1995. An analysis of material requirements planning benefits using alternating conditional expectation. Journal of Operations Management 13 (1), 35-48
McGowan, A., 1998. Perceived benefits of ABCM implementation. Accounting Horizons 12 (1), 31-50.

Kaipia R. and Hartiala H. (2006) "Information-sharing in supply chains: five proposals on how to proceed", Journal of Logistics Management, Vol. 17, No. 3, pp. 377-393

Mendelson, H. (2000), “Organizational architecture and success in the information technology industry", Management Science, Vol. 13, No. 5, pp. 514-31

Ofek, E. and Sarvary, M. (2001), “Leveraging the customer base: creating competitive advantage through knowledge management", Management Science, Vol. 47, No. 11, pp. 1441-56

Graeml, A.R., Balbinot, Z. and Csillag, J. M. (2009), "Internet's Role in the integration of Supply Chains of Manufacturing Organizations in Brazil", Journal of Operations and Supply Chain Management, Vol. 2, No. 2, pp. 9-19.

Kogut, B. and U. Zander (1992). 'Knowledge of the firm, combinative capabilities, and the replication of technology', Organization Science, 3(3), pp. 383- 397

Nonaka, I. (1994). 'A dynamic theory of organizational knowledge', Organization Science, 5, pp. 14-37

Furlong, G. (2001). Knowledge management and the competitive edge. University of Greenwich Business School. http:/ / www.gre.ac.uk/schools/business/Dissertation/ (accessed April 2004).

Cooper, M.C. and Gardner, J.T. (1993), “Building good business relationships - more than just partnering or strategic alliances?", International Journal of Physical Distribution \& Logistics Management, Vol. 23 No. 6, pp. 14-26.

Oliver, C. (1990), “Determinants of interorganizational relationships: integration and future directions", Academy of Management Review, Vol. 15 No. 2, pp. 241-65

Gummesson, E. (1997), "Relationship marketing as a paradigm shift: some conclusions from the 30R approach", Management Decision, Vol. 35 No. 4, pp. 267-72.

Goffin, K., Szwejczewski, M. and New, C. (1997), “Managing suppliers: when fewer can mean more", International Journal of Physical Distributions \& Logistics Management, Vol. 27 No. 7, pp. 422-36.

Spekman, R.E., Kamauff, J. Jr and Myhr, N. (1998), “An empirical investigation into supply chain management: a perspective on partnerships", Supply Chain Management, Vol. 3 No. 2, pp. $53-67$

Kim, K. (1999), “On determinants of joint action in industrial distributor-supplier relationships: beyond economic efficiency", International Journal of Research in Marketing, Vol. 16 No. 3, pp. 217-36.

Leenders, M.R. and Fearon, H.E. (1997), Purchasing and Supply Management, 11th ed., Irwin, London.

Zhenxin, Yu, Hong, H. and Cheng, T. C. (2001) "Benefits of Information sharing with supply chain partnerships", Industrial Management \& Data Systems, Vol. 101 No. 3, pp. 114-119

Cooper, M.C., Ellram, L.M., 1993. Characteristics of supply chain 
management and the implications for purchasing and logistics strategy. International Journal of Logistics Management $4(2), 3-2$

Hahn, C.K., Pinto, P.A., Brag, D.J., 1983. Just-in-time production and purchasing. Journal of Purchasing and Materials Management, 2-10, Fall.

Choi, T.Y., Hartley, J.L., 1996. An exploration of supplier selection practices across the supply chain. Journal of Operations Management 14, 333-343.

De Toni, A., Nassimbeni, G., 1999. Buyer-supplier operational empirical research. International Journal of Production Research 37 (3), 597-619.

Carr, A.S., Pearson, J.N., 1999. Strategically managed buyerseller relationships and performance outcomes. Journal of Operations Management 17, 497-519.

Dwyer, F.R., Schurr, P.H., Oh, S., 1987. Developing buyer-seller relationships. Journal of Marketing 51 (2), 11-27.

Noordewier, T.G., John, G., Nevin, J.R., 1990. Performance outcomes of purchasing arrangements in industrial buyer-vendor relationships. Journal of Marketing 54 (4), 80-93.

Han, S., 1993. Buyer-supplier relationships today. Industrial Marketing Management 22(4), 331-338.

Larson, P.D., 1994. An empirical study of inter-organizational functional integration and total costs. Journal of Business Logistics 15 (1), 153-169.

Zeller, T.L., Gillis, D.M., 1995. Achieving market excellence through quality: the case of Ford Motor. Business Horizons 38 (3), 23-31.

Souza Filho, O. V., Martins, R. S. and Pereira, S. C. F.(2008), “Strategic Alignment in the

Brazilian Automotive Chain: Relationships Between First and Second Tier Journal of Operations and Supply Chain Management Vol.1, No. 1, pp.41-56

Freires, F.G. M. and Alcibíades Paulo S. Guedes, A. P. S. (2008), "Power and Trust in Reverse Logistics Systems for Scraptires and its Impact on Performance", Journal of Operations and Supply Chain Management, Vol. 1, No. 1 pp. 57-65
Welman, J.C.,\& Kruger, S.J. (2001).Research Methodology (2nd Ed.). Cape Town: Oxford University Press

Iyer, A. V. and Bergen, M. E. (1997), “Quick response in manufacturer-retailer channels", Management Science, Vol. 43, pp. 559-70.

Baganha, M. P. and Cohen, M. A. (1998), "The stabilizing effect of inventory in supply chains", Operations Reearch, Vol. 46, pp. s72-s83.

Taylor, Z. "The Effect of Incentives on Knowledge Sharing in Computer-Mediated Communication: An Experimental Investigation," Journal of Information Systems 20(1), 2004, pp: 103-116.

Dyer, J.H. and H. Singh. "The Relational View: Cooperative Strategy and Sources of Interorganizational Competitive Advantage," Academy of Management Review, (23:4), 1998, pp. 660-679

Andersen, P.H. and P.R. Christensen. "Inter-Partner Learning in Global Supply Chains: Lessons from NOVO Nordisk," European Journal of Purchasing \& Supply Management, (6:2), 2000, pp. 105-116.

Ha ${ }^{\circ}$ kansson, H., V. Havila and A.-C. Pedersen. "Learning in Networks," Industrial Marketing Management, (28:5), 1999, pp. $443-452$

Bessant, J. "Supply Chain Learning." In R. Westbrook andS. New (Eds.), Understanding Supply Chains: Concepts, Critiques, Futures, Oxford University Press, Oxford, 2004, pp. 165-190

Lessler, J., Kalsbeek,W., 1992. Nonsampling Error in Surveys.Wiley, New York

Dawes, John (2008). “Do Data Characteristics Change According to the number of scale points used? An experiment using 5-point, 7-point and 10-point scales". International Journal of Market Research 50 (1): 61-77.

Hair, J.F., Anderson, R., Tatham, R., Black, W., 1998. Multivariate Data Analysis. Prentice Hall, Upper Saddle River, NJ.

Nunnally, J., 1994. Psychometric Theory. McGraw-Hill, New York

http:/ / www.gseis.ucla.edu/coures/ed230b/notes/handout7. pdf [Accessed in March 17, 2010] 


\section{AUTHOR'S BIOGRAPHY}

Choudhury Abul Anam Rashed is an Assistant Professor in the Department of Industrial and Production Engineering in Shahjalal University of Science and Technology, Bangladesh. His research interests include Supply Chain Managment. His publications have appeared in peer reviewed journal such as International Journal of Innovation, Management and Technology. His research has been presented in quite a number of international conferences including Conference on Industrial Engineering and Operations Management (IEOM), Conference on Engineering Research, Innovation and Education (CERIE) etc.

Abdullahil Azeem is a Professor in the Department of Industrial and Production Engineering in Bangladesh University of Engineering and Technology, Bangladesh. He obtained his PhD degree from the University of Western Ontario, Canada. His research interests include scheduling and inventory management using artificail intelligence, supply chain management, automated manufacturing system etc. His publications have appeared in many peer reviewed journals such as International Journal of Production Economics, International Journal of Machine Tools and Manufacture, International Journal of Advanced Manufacturing Technology, Journal of Industrial Engineering and Management, International Journal of Integrated Supply Chain Management, Global Journal of Business and Management, International Journal of Quality and Innovation etc.

Zaheed Halim is currently pursuing his PhD in Deakin Univerisity. He has worked in public as well as private universities in Bangladesh as an academician. He has mainly lectured on Operations Management, Supply Chain Strategy and Business Research Methods. His articles has been published in SCM: An International Journal and Journal of Occupational Safety and Ergonomics. His research has been presented in quite a number of international conferences including Academy of Management, IBIMA etc. His research interest includes partnerships in supply chains and supply chain risk. His present research focus on supply chain complexity and its impact on the supply chain visibility and performance. 